\title{
Prosperous Justice Party (PKS) Image Management In The 2019 Election*
}

\author{
Fahmi Azhari Siregar', Gun Gun Heryanto ${ }^{2}$, Munadhil Abdul Muqsith ${ }^{3}$, \\ Refly Setiawan ${ }^{4}$ \\ 1,2 Syarif Hidayatullah State Islamic University, Jakarta, Indonesia \\ ${ }^{3}$ Peoples' Friendship University of Russia (RUDN University), Moscow, \\ Russia \\ ${ }^{4}$ Kazan Federal University, Kazan, Russia \\ d. \\ 10.15408/sjsbs.v7i11.18777
}

\begin{abstract}
:
Prosperous Justice Party (PKS) is one of the largest Islamic-based parties in Indonesia. Ahead of the 2019 general election, PKS received an internal solidity endurance test and externally as the government's opposition. PKS requires communicative performance to improve its image in the 2019 election. Departing from these problems, researchers are interested in knowing how the PKS communicative performance in the 2019 legislative elections and the PKS Political Public Relations Approach in the 2019 elections. This research uses the main theories of communicative performance, which Michael Pacanowsky and Nick O'Donnell-Trujillo and the concept of Public Relations Politics to explain the management of the PKS image in the 2019 legislative elections. This study uses qualitative research methods, with library studies, documentation, and interviews. Besides, this research also uses the Norman Fairclough critical paradigm approach. The object of this research study is the board of the Central Prosperous Justice Party (DPP PKS) Board of Representatives and PKS Legislative Members in the Indonesian House of Representatives (DPR). The findings of this research indicate, Communicative Performance of PKS in the 2019 Election in Ritual Performance, each party's decision making is collective. Political Public Relations Approach is not maximized in a political marketing approach, and it needs its management to improve the image of PKS. The results of this study indicate that PKS is weak in issue management, and PKS Communicative Performance in the 2019 elections is quite good even though the performance of persuasion is less effective. Also, the Persuasive Political approach is less effective for PKS.
\end{abstract}

Keywords: Image Management, Prosperous Justice Party (PKS), 2019 Elections

* Received: July 3, 2020, Revision: July 28, 2020, Published: November 1, 2020.

${ }^{1}$ Fahmi Azhari Siregar is Master's Alumni at Syarif Hidayatullah State Islamic University, Jakarta, Indonesia. Email: Fahmiazharysiregar@gmail.com

${ }^{2}$ Gun Gun Heryanto is a Lecturer at Syarif Hidayatullah State Islamic University, Jakarta, Indonesia. Email: Gun.heryato@uinjkt.ac.id

3 Munadhil Abdul Muqsith is a PhD Student of Communication at Peoples' Friendship University of Russia (RUDN University), Moscow, Russia. Email: Munadhil.muqsith@gmail.com

${ }^{4}$ Refly Setiawan is a Master's Student of Political Science at Kazan Federal University, Kazan, Russia. Email: refly@ubl.ac.id 


\begin{abstract}
Abstrak:
Partai Keadilan Sejahtera (PKS) adalah salah satu partai berbasis Islam terbesar di Indonesia. Menjelang Pemilu 2019, PKS mendapatkan uji ketahanan internal soliditas dan secara eksternal sebagai oposisi pemerintah. PKS menuntut kinerja komunikatif untuk meningkatkan citranya di Pemilu 2019. Berangkat dari permasalahan tersebut, peneliti tertarik untuk mengetahui bagaimana kinerja komunikatif PKS pada Pemilu Legislatif 2019 dan Pendekatan Humas Politik PKS pada Pemilu 2019. Penelitian ini menggunakan teori utama kinerja komunikatif yaitu Michael Pacanowsky dan Nick O'Donnell-Trujillo serta konsep Public Relations Politics untuk menjelaskan pengelolaan citra PKS pada Pemilu Legislatif 2019. Penelitian ini menggunakan metode penelitian kualitatif, dengan studi pustaka, dokumentasi, dan wawancara. Selain itu, penelitian ini juga menggunakan pendekatan paradigma kritis Norman Fairclough. Objek penelitian ini adalah pengurus Dewan Perwakilan Rakyat Partai Keadilan Sejahtera Pusat (DPP PKS) dan Anggota Legislatif PKS di Dewan Perwakilan Rakyat Indonesia (DPR). Temuan penelitian ini menunjukkan, Kinerja Komunikatif PKS pada Pemilu 2019 dalam Pelaksanaan Ritual, pengambilan keputusan masing-masing pihak bersifat kolektif. Pendekatan Political Public Relations belum dimaksimalkan dalam pendekatan pemasaran politik, dan perlu pengelolaannya untuk meningkatkan citra PKS. Hasil penelitian ini menunjukkan bahwa PKS lemah dalam pengelolaan isu, dan Kinerja Komunikatif PKS pada Pemilu 2019 cukup baik meskipun kinerja persuasi kurang efektif. Selain itu, pendekatan Politik Persuasif kurang efektif untuk PKS.
\end{abstract}

Kata Kunci: Pengelolaan Citra, Partai Keadilan Sejahtera (PKS), Pemilu 2019

\title{
A. INTRODUCTION
}

Prosperous Justice Party (PKS) received 11,493,663 votes or $8.22 \%$ of the legislative election votes in 2019 based on the results of the KPU's tiered results. The data shows the vote acquisition trend of the Sejahatera Justice Party rose by $1.42 \%$ of the national vote. Quoted from the 2013 General Election kpu.go.id., previously only received $6.79 \%$ of the vote in the 2014 election. Not only did PKS get an increase, but the Indonesian Democratic Party of Struggle (PDIP) also gained 27,053,961\% of the votes. Followed by other parties, getting an increase in votes is the Great Indonesia Movement Party (Gerindra) 17,565,839 votes quoted from kpu.go.id.

Table 1: Rise in Political Parties $2019^{5}$

\begin{tabular}{ccccc}
\hline $\begin{array}{c}\text { Political } \\
\text { Parties }\end{array}$ & $\begin{array}{c}\mathbf{2 0 1 9} \\
\text { election }\end{array}$ & $\begin{array}{c}\text { Chairs } \\
\text { amount }\end{array}$ & $\begin{array}{c}\mathbf{2 0 1 4} \\
\text { election }\end{array}$ & $\begin{array}{c}\text { Chairs } \\
\text { amount }\end{array}$ \\
\hline PDIP & 27.053 .961 & 128 & 23.681 .471 & 109 \\
Gerindra & 17.565 .839 & 85 & 14.760 .371 & 73 \\
PKB & 13.570 .097 & 58 & 11.298 .957 & 47 \\
Nasdem & 12.661 .792 & 59 & 8.402 .812 & 35 \\
PKS & 11.493 .663 & 50 & 8.480 .204 & 40 \\
\hline
\end{tabular}

Source Online media "Kompas.com" (processed data)

${ }^{5}$ Researcher Processed from Online Media “Kompas.com” Accessed on September 10, 2019 
Based on the table, the researcher shows the votes of political parties for seats in the Indonesian House of Representatives (DPR RI) in the 2019 elections and the votes for political parties in $2014^{6}$. They were processed from several national online media sources. Political parties in the 2019 elections experienced a significant increase. Indonesian Democratic Party of Struggle (PDIP) has recorded an additional 19 seats. Followed by the Great Indonesia Movement (Gerindra) received five seats, the National Awakening Party (PKB) received an additional 11 seats. The Democratic National Party (Nasdem) gained 23 seats, the last to get more seats was the Prosperous Justice Party from 40 seats to 50 seats. So, PKS received the addition of 10 seats in the Indonesian Parliament.

Nine political parties escaped to the Senayan building based on the vote acquisition in the 2019 election, based on data processed from republika.co.id. The third highest-ranking vote was the Golkar Party 17,229,789 or $12.31 \%$ of the votes; the Golkar Party went down in the 2019 elections. The fourth-ranking was PKB, 13,570,097, or $9.69 \%$ of the votes. The five parties were ranked Nasdem $12,661,792$ votes or $9.05 \%$. PKS Party $11,493,663$ votes or $8.22 \%$ of the vote. Democratic Party with 10,876,507 votes or $7.77 \%$ of the vote. PAN party with $9,572,623$ votes or $6.84 \%$. PPP party with $6,323,147$ votes or $4.52 \%$ of the vote.

While the other seven parties certainly did not qualify, based on data processed from cnnindonesia.com, the PSI party with 2,650,361 votes $(1.89 \%)$, the Perindo party with $3,738,320$ votes $(2.67 \%)$, and the Karya party with $2,929.495$ votes $(2.09 \%)$. Then the Hanura party with $2,161,507$ votes (1.54\%), the UN party with $1,099,848(0.79 \%)$, the Garuda party with 702,536 (0.50\%), and the PKPI party 312,775 (0.22\%).

Indonesia is a country with a majority Muslim population. Although not formally mentioned in the state constitution, Islam continues to be an important political force in Indonesian history, where almost $80 \%$ of the population is Muslim ${ }^{7}$. It is undeniable that PKS voters are the majority Muslim community.

Quoted and processed from kpu.go.id, such as the PPP party, the PAN party, the Democratic party in the 2014 election won 12,728,913 (10.9\%) votes, 2019 dropped to $10,876,507(7.77 \%)$ votes, dropped ( 3.13\%) votes. The Hanura Party in the 2014 election won 6,579,498 (5.26\%) votes, 2019 dropped to 2,161,507 (1.54\%) votes, down $(3.72 \%)$ votes. PKS party tends to increase $1.42 \%$ of the vote.

${ }^{6}$ Muqsith M.A. (2019). The Relationship of Political Socialization Messages Relations In Social Media Twitter With The Image Of PKS. (Study: Political Socialization PKS Through@PKSejahtera Account). Jurnal Ilmu Komunikasi Ekspresi dan Persepsi. 2019. Vol 2 No. 1 P. 3-12.

\footnotetext{
${ }^{7}$ Heryanto, G. G. (2019). Literasi Politik Dinamika Konsolidasi Demokrasi Indonesia Pasca reformasi.Yogyakarta: Ircisod.
} 
Table 2: Voters Down in the 2019 Elections $^{8}$

\begin{tabular}{ccccc}
\hline $\begin{array}{c}\text { Political } \\
\text { Parties }\end{array}$ & $\mathbf{2 0 1 9}$ & $\begin{array}{c}\text { Chairs } \\
\text { amount }\end{array}$ & 2014 & $\begin{array}{c}\text { Chairs } \\
\text { amount }\end{array}$ \\
\hline GOLKAR & 17.229 .789 & 85 & 18.432312 & 91 \\
DEMOKRAT & 12.728 .913 & 54 & 10.876 .507 & 61 \\
PAN & 9.572 .623 & 44 & 9.481 .621 & 49 \\
PPP & 6.323 .147 & 19 & 8.157 .488 & 39 \\
\hline \multicolumn{4}{c}{ Source Online media “Kompas.com" (processed data) }
\end{tabular}

The table above shows the vote of the old party going down in the 2019 election. Researchers also compared the 2014 election, starting with the National vote and decreasing the number of seats in the DPR RI, processed from several National news sources.

After changing its name to PKS and participating in the 2004 elections, PKS received $7.34 \%$ of the votes and got 45 seats in the Indonesian Parliament. Quoted from kompas.com, in the 2009 elections, PKS won $7.88 \%$ of the votes and 57 seats in the Indonesian Parliament. It can be concluded that PKS votes from 1999 to 2019 elections tended to increase. When referring to other Islamic base parties, only PKS can raise the vote significantly in the 2019 election. Other Islamic parties, which can only raise a few numbers, tend to decrease.

PKS has participated in the elections five times, often predicted to fall; in fact, the party which was once named PK has only experienced a decline in votes in the 2014 election.

Table 3: PKS Votes During the Election ${ }^{9}$

\begin{tabular}{ccccc}
\hline Year & Vote & Percent & Chair & Year \\
\hline 1999 & 1.436 .565 & $1,36 \%$ & 7 & 1999 \\
2004 & 8.325 .020 & $7,34 \%$ & 45 & 2004 \\
2009 & 8.204 .946 & $7,88 \%$ & 56 & 2009 \\
2014 & 8.480 .204 & $6,7 \%$ & 40 & 2014 \\
\hline \multicolumn{5}{c}{ Source Online media “Kompas.com" (processed data) }
\end{tabular}

The table below shows the vote acquisition of PKS and the number of seats in the DPR RI during the election from 1999 to 2019, processed from several national online media.

The peak of the PKS decline during the period of the PKS Party President was in the period 2010-2015 when Lutfi Hasan Ishak, considered the Corruption Eradication Commission (KPK) on January 29, 2013, was a result of a cattle import quota case. PKS is slowly making various efforts to minimize the effects of the problem

${ }^{8}$ Researcher Processed from Online Media "Kompas.com" Accessed on September 10, 2019

${ }^{9}$ Researcher Processed from Online Media "Kompas.com" Accessed on September 10, 2019 
so that it does not extend to the image of the party. But in general, the PKS image is still relatively good. ${ }^{10}$ PKS is a party that is seen by the public as a party with only a few corrupt elites. Compared to other parties, PKS seems to be seen by the public as being relatively clean. It was proven that the decline in votes was only 17 seats in the Indonesian Parliament.

In the 2019 elections, PKS built image management, so that it could be accepted by the public. Among other things, the PKS portrayed itself about its closeness to the ulema and fought for a law on the abolition of taxes and driving licenses that lasted for life, supported Prabowo-Sandi, and actions to defend Islam 212 as quoted from various media sources. Community response is quite satisfying.

\section{B. METHODS}

The method used in this study is a qualitative research method using two main approaches, namely library and field research. Literature research is done by examining several books, articles, research reports, journals, and others. ${ }^{11}$ Besides, library research is also carried out through electronic exploration (internet) and print media (newspapers and magazines) related to the subject of this study.

This study uses one leading theory, Communicative Performance, and is supported by two concepts, namely the image approach and the Political Relations Public approach. Image management, researchers position it as a research locus. Image management as management will be the researcher's analysis of communicative performance and public relations approach to politics. The researcher also added a SWOT analysis to evaluate strengths, weaknesses, opportunities, and threats to describe the management of the PKS image in the 2019 election.

The other primary source of information is field research, carried out in Jakarta and at many PKS political bases in the PKS Central Representative Council and the PKS Faction office of the DPR of the Republic of Indonesia. Field research was carried out to obtain essential materials such as documentary evidence and PKS archives and official statements of the PKS Central Committee Member, PKS DPR RI faction bulletin, books, and print media. The purpose of this approach is to explain the most in-depth phenomena through data collection. Qualitative research, according to Kirk and Miller ${ }^{12}$, is a specific tradition in social science that is fundamentally dependent on human observations, both in the region and in its terminology.

In this research, data will be obtained through a study of documentation or a review of the news of the PKS Central Representative Council in the media. Besides, in

${ }^{10}$ Mulyana, D. (2013). Komunikasi Politik Politik Komunikasi, Membadah Visi dan Gaya Komunikasi Praktisi Politik. Bandung: PT. Remaja Rosdakarya.

${ }^{11}$ Setiawan, R. (2017). Partisipasi Publik Dalam Program Bantuan Listrik Pedesaan Masyarakat Kabupaten Mesuji. Jurnal e-JKPP. Vol. 3 (3)

${ }^{12}$ Nurul, H. (2006). Metodologi Penelitian Dakwah Dengan Pendekatan Kualitaif. Jakarta: UIN Jakarta Press. 
collecting data, researchers used interview techniques, literature, and research informants.

\section{RESULTS AND DISCUSSION}

\section{Communicative Performance Theory Michael Pacanowsky and Nick O'Donnell- Trujillo}

Theories about organizational culture emphasize the ways humans shape organizational reality. As research on the way of life of organizations, this approach looks at the meaning and value of members ${ }^{13}$.

This approach examines the way individuals use stories, rituals, symbols, and other activities to produce and reproduce understanding. The organizational culture movement has very broadly touched almost all aspects of organizational life ${ }^{14}$. The essence of organizational life can be found in the culture of the organization concerned. The organization can also be said as a place to achieve a predetermined goal ${ }^{15}$.

In this case, the word culture itself does not refer to things such as ethnicity, ethnicity, or cultural background of a person, but according to Pacanowsky and Trujillo, culture is a way of life in the organization (Away Of Living) included in the organizational culture is the climate or emotional atmosphere and psychologically including the morale, attitude, and level of productivity of the employees or members of the organization concerned.

Pacanowsky and Trujillo present a list of many organizational communication shows consisting of ritual, passion, social, political, and enculturation performances ${ }^{16}$.

a. Ritual Performance is something that is repeated regularly (routinely) so that it can be recognized properly. Ritual performances are communication shows that occur regularly and repeatedly, for example, meetings or annual picnic events.

b. Performance Desire is a hobby or a favorite. Here, employees try to make boring routine work interesting and fun by telling stories (storytelling) that are favored or liked. In other words, passion is stories in organizations that are often conveyed by one member to other members of the organization.

c. Social Performance is various forms of politeness, small talk, respect that is done maximally to encourage and enhance cooperation among other members of the organization.

\footnotetext{
${ }^{13}$ Kerlinger. (2015). Metode Penelitian Komunikasi Prosedur, Tren, Dan Etika. Bandung: Simbiosa Rekatama Media.

${ }^{14}$ Stephen, W. L., \& Karen, A. F. (2009). Teori Kounikasi (Theories Of Human Communication) Edisi 9. Jakarta Selatan: Salemba Humanika.

${ }^{15}$ Farida I., \& Setiawan, R. (2018). Leadership In Cope With Prostitute In Social Department of Bandar Lampung. International Journal of Social Sciences And Development, Vol. 2 (1). 1-8. doi: 10.24967/saburaiijssd.v2i1.325

${ }^{16}$ Morissan. (2009). Teori Komunikasi Organisasi. Bogor: Ghalia Indonesia.
} 
d. Performance The politics of performance creates and reinforces ideas about power and influence, which includes behavior to show personal strength, strengthen relationships or fellowship, and bargain.

e. Enculturation Performance is how members get the knowledge and expertise to be able to become members of an organization that can contribute.

There are several types of communicative performance following a brief explanation in the tabular show some brief stages of communicative performance in processing data.

Table 4: Cultural Performance in Organizations

\begin{tabular}{ll}
\hline \multicolumn{1}{c}{ Performance } & \multicolumn{1}{c}{ Explanation } \\
\hline Ritual & $\begin{array}{l}\text { An activity, task, work, which is repeated } \\
\text { regularly (routinely) in the organization so that it } \\
\text { can be recognized properly } \\
\text { Stories about organizations that are often told } \\
\text { enthusiastically by members of the organization } \\
\text { wesire }\end{array}$ \\
& $\begin{array}{l}\text { Courtesy and politeness to encourage cooperation } \\
\text { among members of the organization }\end{array}$ \\
Social & $\begin{array}{l}\text { power or control When members of an } \\
\text { organization are involved in political } \\
\text { performance, they communicate a desire to } \\
\text { influence others }\end{array}$ \\
Enculturation & $\begin{array}{l}\text { expertise to be able to become a member of an } \\
\text { organization that can contribute to the } \\
\text { organization }\end{array}$
\end{tabular}

\section{Political Imagery}

Political image is the image or reputation associated with a political party or a person who has a career in politics that is perceived by the wider community. Every party founded has its image. And this image can be used as a strategy in winning the voting contestation ${ }^{17}$. Besides that, $\mathrm{Nimmo}^{18}$ also explained the image that both the sound attributes and perspectives did not determine the choice of the voters. However, voters selectively perceive parties, candidates, issues, and events in the campaign, give meaning to them and, based on that, determine the voting. Through an interpretive process, they not only take into account their attributes and developments, which are long-term images but also compile short-term images of campaign objects.

${ }^{17}$ Mulyana, D. (2013). Komunikasi Politik Politik Komunikasi, Membadah Visi Dan Gaya Komunikasi Praktisi Politik. Bandung: PT. Remaja Rosdakarya.

${ }^{18}$ Nimmo. (2010). Komunikasi Politik: Khalayak dan Efek. Bandung: PT. Remaja Rosdakarya. 
The formation of a political image is obtained through mutual trust, values, and expectations embodied in the form of personal opinion, furthermore developed into public opinion. Public opinion can arise from people's thoughts on an object that is judged ${ }^{19}$. The formation of the party's image is based on information that we get directly through interpersonal communication or through mass media that is used as political media, including the mass media designated to inform the latest political message ${ }^{20}$.

Political image is related to political socialization because the political image is formed through the process of political learning, both directly and through empirical experience. The political image includes several things, namely:

a. All one's political knowledge is right or wrong.

b. All preferences (affections) are attached to certain stages of interesting political events.

c. All expectations that people have about what might happen if he behaves in a changing manner ${ }^{21}$.

There are four stages in imaging, according to Baudrillard. First, imaging is a reflection of basic reality. Second, it covers and misleads basic reality. Third, cover up the absence of basic reality. Fourth, it does not refer to or have relations with any reality ${ }^{22}$. It is at this stage that perfect simulations emerge. The basic reality of the elections is the procession of gaining authority from the people to the chosen leader.

\section{Types of Imagery}

According to Frank Jefkins ${ }^{23}$ in the public relations book, there are several images, namely:

a. Mirror Image. This image adheres to insiders or members of the organization, usually the leader regarding outsiders' perceptions about the organization. In another sentence, a shadow image is an image held by an insider regarding an outside view of his organization. This image is often inaccurate, even just an illusion, as a result of the inadequacy of information, knowledge, or understanding possessed by those within the organization regarding the opinions or views of outsiders.

b. Current Image. An image or view held by outsiders on an organization and an individual, which is determined by the amount of information they receive, is constructed by them and is trusted.

\footnotetext{
19 Setiawan, R. (2016). Peranan Etika Aparatur Sipil Negara Dalam Pelayanan Publik Pada Dinas Kependudukan Dan Catatan Sipil (Disdukcapil) Kota Bandar Lampung. Jurnal e-JKPP. Vol. 2 (2)

${ }^{20}$ Ardial. (2008). Komunikasi Politik. Medan: PT. Indeks.

${ }^{21}$ Arifin, A. (2011). Komunikasi Politik. Yogyakarta: Graha Ilmu.

${ }^{22}$ Heryanto, G.G, Komunikasi Politik Di Era Industry Citra, (Jakarta: PT. Laswell Visitama, 2010).

${ }^{23}$ Jefkins, F. (2003). Public Relations, Edisi Kelima, Terjemahan Daniel Yadin. Jakarta: Erlangga.
} 
c. Multiple Image. The existence of a variety of images from the public towards certain organizations is caused by those who represent the organization with different behaviors or not in tune with the goals or principles of the organization.

d. Corporate Image. The image of the organization as a whole, not just the image of its products and services.

e. Wish Image (Expected Image). An image desired by management or an organization The expected image is usually formulated and applied to new ideas or brands when the audience does not have sufficient information about them. This image of hope can be a new creation or transformation from an old image that is considered to be expired.

\section{General Concept of PKS Image Management in 2019 Elections}

Researchers used the Wish Image approach (expected image) to get a picture of PKS image management in the 2019 election. Frank Jefkins said in the Public Relations book. An image desired by management or an organization. The expected image is usually formulated and applied to new ideas or brands when the audience does not have sufficient information about them. This image of hope can be a new creation or transformation of an old image that is considered to have expired ${ }^{24}$.

As PKS did in the 2019 elections, PKS made it happen with the tagline of "Berkhidmat untuk Rakyat" or "Serving the People" one of the big concepts for PKS in the 2019 elections from the start. Quoted from pks.id, since its inception, PKS has the aim of giving service to the Indonesian people, and to contribute even more to the progress of the nation and state. The PKS tagline has never shifted to continue "Serving the People". Meaning the tagline is the spirit of the PKS as outlined in real work to the people, this spirit is not just imaging, but consistency.

PKS always uses different taglines in each election. Quoted from republika.co.id, even though the tagline continues to change, but the slogan "Bersih, Peduli, Profesional" or "Clean, Caring, Professional" will still be used in each period of management. This slogan can not be eliminated because it is already included in Article 2 ayat 2 articles of association.

The basic principle is "Clean, Caring, Professional" these three words are the initial slogan of the PKS before being replaced by the previous PKS President Anis Matta. Quoted from news.detik.com, Anis Matta changed the PKS slogan to "Cinta, Kerja, dan Harmoni" or "Love, Work And Harmony" when he was appointed as PKS President replacing Lutfi Hasan Ishak. According to the PKS President, Muhammad Sohibul Iman wanted to return the PKS to its original ideals of being a "Clean, Caring And Professional" party.

${ }^{24}$ Jefkins, F. (2003). Public Relations, Edisi Kelima, Terjemahan Daniel Yadin. Jakarta: Erlangga. 
Quoted from researcher interviews with Agoes Purnomo ${ }^{25}$, head of the Department of Political Analysis for the Election and Election (BPPP) of the PKS Central Representative Council, said that.

The meaning of "Serving the People" was taken by the fourth precepts of the Pancasila, which reads "democracy led by wisdom in deliberation and representation" from where it was taken back to the tradition of hard work, like PKS, defending the people, being honest and looking forward. The tagline selection process starting from the syuro assembly is discussed in the agenda of the five-year meeting and submitted to the party president carried out, anything related to solemnity to be carried out with the management of the other Central Representative Council (DPP), after being stipulated in the General Assembly then passed to the Regional Representative Council (DPW), Regional Representative Council (DPD), Branch Representative Council (DPC), branches, participate in implementing and socializing the tagline. (Agoes Purnomo).

This was also reinforced by quotations from researchers' interviews with Ledia Hanifa $^{26}$, Chairperson of the PKS DPP Public Relations:

"The concept established by the PKS in the 2019 election through the tagline" respect for the people, "when using the tagline all must follow, whether there is the activity or no election activities must continue to do, from there the respect was formed." (Ledia Hanifa)

After the PKS tagged "Serving the People" was not satisfied, PKS finally made a new hashtag \#ayolaikaik, proposed and formulated by the Election Committee and Regional Election (BPPP) DPP PKS, together with Public Relations DPP PKS, at the branding training event held at the MD DPP office PKS, at the same time invited several figures from various circles. Quoted from a researcher interview with, Agoes Purnomo ${ }^{27}$, Chair of the Department of Political Analysis for the Election and Election (BPPP) DPP PKS, said.

"Hashtag \#AyoLebihBaikor \#Let'sGetBetter like the character of PKS, in the context of the interests of the election, if only"Serving the People"does not involve the public, it tends to be cool, after the decision of the meeting assembly is good for branding, in the sense of legal branding that we are ready to honor for the people, after they are formed, we submit them to PR, to be compared."

We argue the role of PKS DPP public relations (PR) is significant in this regard; public relations becomes a bridge of communication to the public and creates a better understanding of the people. PR has the responsibility to provide information, educate, convince the public in a situation

${ }^{25}$ Results of Interview with: Agoes Purnomo, Head of the Department of Political Analysis in the Election and Pilkada (BPPP) DPP PKS Field. On November 2, 2019, at DPP PKS, Jalan TB. Simatupang, South Jakarta.

${ }^{26}$ Results of Interview with: Ledia Hanifa, Head of Public Relations (PR) DPP PKS. On October 14, 2019, at the DPR / MPR RI Building, Fourth Floor, Senayan, South Jakarta.

${ }^{27}$ Results of Interview with: Agoes Purnomo, Head of the Department of Political Analysis in the Election and Pilkada (BPPP) DPP PKS Field. On November 2, 2019, at DPP PKS, Jalan TB. Simatupang, South Jakarta. 
The role of PKS public relations is significant in this regard, building a positive reputation through hashtag \#Let'sGetBetter to the public. Nowadays, the media is becoming a political tool for political campaigns in Indonesia and today is far more open and transparent than in previous decades. The public is increasingly critical in seeing current political problems through the media.

Quoted from researcher interviews with Chairman of the PKS DPP PKS Department Igo Ilham ${ }^{28}$ to researchers. PKS forms the optimization of the public relations body in the PKS DPP.

"This is a body that has a primary task (main task) that builds mass relations with various media, both media that are offline or usually now called mainstream media and social media and this task institutionally, this task is with them, so they build communication with media with reporters to convey the image of PKS."

In public relations, PKS encourages \#Let'sGetBetter has entered two years before the election like Ledia Hanifa ${ }^{29}$ said:

"Hashtag \#Let'sGetBetter to part of da'wah, inviting all people better. This is under the vision of the PKS mission" respect for the people "continuously conveyed to the public through social service activities, service actions, flashmob, and external and internal media."

We conclude that the general concept of PKS in the 2019 election is to invite the public in goodness as outlined in the tagline "Serving the People" Although it differs in every PKS arrangement, it does not leave the slogan "clean, caring and professional" because it is included in the party's statutes or articles of association.

\section{PKS image in the 2019 elections}

The 2019 PKS election imaged itself as a party that was pro-people, caring, and quick to act. This image management concept was outlined in the PKS idea campaign conducted in the 2019 election. Quoted from the researcher interview with the Chairperson of the Election and Election (BPPP), DPP PKS Choirul Anwar ${ }^{30}$ said.

"The political campaign of ideas carried out by PKS cadres received a response from the community. Moreover, PKS conducts campaigns by taking to the streets to do flashmob. The flashmob's enthusiasm received a lot of welcome from the public, because it directly interacted with the people in the field, besides conveying the politics of ideas, while carrying out campaign activities. Why are the political promises of ideas highlighted and carried out by PKS in the 2019 elections, because they are in line with the tagline "Serving the People."

${ }^{28}$ Results of Interview with: Igo Ilham, Head of the Department of Da'wah Development for Community Development (BPU) DPP PKS. On December 16, 2019, in Kebagusan, South Jakarta.

${ }^{29}$ Results of Interview with: Ledia Hanifa, Head of Public Relations (PR) DPP PKS. On October 14, 2019, at the DPR / MPR RI Building, Fourth Floor, Senayan, South Jakarta.

${ }^{30}$ Results of Interview with: Choirul Anwar, Chairman of the Election and Pilkada (BPPP) DPP PKS Division. On September 4, 2019, at the DPR / MPR RI Building, Fourth Floor, Senayan, South Jakarta. 
Quoted from pks.id, flashmob activities became a venue for the delivery of political ideas. PKS conveyed to the public related to campaign promises, namely the abolition of motorcycle tax, the enactment of a lifetime driver's license, the protection of scholars, religious leaders, and religious symbols, and, most recently, the abolition of taxes for those who earn up to Rp.8 million.

The political campaign of ideas carried out by PKS, according to several informants interviewed by researchers, said. The promise of PKS in the 2019 elections, one way to boost PKS votes includes:

\section{a. Fighting for the Motorcycle Tax Write Off Bill}

Quoted from detik.com PKS will fight for the draft law on abolishing motorcycle tax and enacting a lifetime license when winning the 2019 election. According to PKS, this method will reduce the burden on the community. Quoted from researcher interviews with Al Muzammil Yusuf ${ }^{31}$, Chair of the Political Law and Human Rights (Polhukam) DPP PKS.

Motorbike tax referred to is motor vehicle tax (PKB), motor vehicle transfer tax (PBBNKB), Mandatory Road Traffic Accident Funding Donation Fees, administrative costs for Vehicle Number Marks (STNK), and administrative costs for Motorized Vehicle Number Marks (TNKB) for small cc motorcycles. PKS wants to ease the burdens of people's lives, which are getting heavier with demands to pay various kinds of costs ".

According to PKS, the elimination of all financial and non-financial obligations, both owed due to postponement of payments in the past aka delinquent or financial obligations in the current year. Quoted from researcher interviews with Pipin Sopyan ${ }^{32}$, Chair of the Political and Legal Political and Legal Affairs Department (Polhukam) of the PKS DPP.

"The reason PKS is fighting for the Motorcycle Tax Write-off Bill is to eliminate this tax to ease the burden on people's lives. Reducing hassles, complexity, and lost productive time. Elimination of this tax will not significantly disrupt the finances of the Provincial APBD. "

\section{b. The application of a driver's license for life}

Meanwhile, related to the implementation of the driver's license program for life, quoted from tribunnews.com reported, PKS will apply it for SIM A, SIM B1, SIM B2, SIM C, and SIM D. Al Muzzammil Yusuf ${ }^{33}$ said the replacement of the SIM every five years troublesome Society. Another reason for PKS is to ease the burden on

${ }^{31}$ Results of Interview with: Al Muzammil Yusuf, Head of Political, Legal and Human Rights (Polhukam) DPP PKS. On September 2, 2019, at the DPR / MPR RI Building, Fourth Floor, Senayan, South Jakarta.

32 Results of Interview with: Pipin Syofyan, Chair of the Political, Legal and Human Rights (Polhukam) Department of DPP PKS. On October 13, 2019, at the DPR / MPR RI Building, Fourth Floor, Senayan, South Jakarta.

${ }^{33}$ Results of Interview with: Al Muzammil Yusuf, Head of Political, Legal and Human Rights (Polhukam) DPP PKS. On September 2, 2019, at the DPR / MPR RI Building, Fourth Floor, Senayan, South Jakarta. 
Society. Besides, they also saw several other countries that had implemented the program.

It is excerpted from researcher interviews with Pipin Sopyan ${ }^{34}$, Chair of the Political and Legal Political and Legal Department (Polhukam) DPP PKS.

"The reason for applying a lifetime SIM according to SIM renewal once every five years is troublesome, successful Evidence is the National Identity Card (KTP) which must be renewed once every five years now for a lifetime and has a positive effect on saving people's productive time. For the fees paid by the community to be light enough, I have to pay the cost of making a SIM. "

\section{c. Income Tax 8 Million Per Month Tax-Free}

According to PKS the two phrases "justice" and "welfare" which constitute the mandate of the constitution are truly the spirit of the PKS struggle so far. Quoted from a researcher interview with Pipin Sopyan ${ }^{35}$, Chair of the Political and Legal Political and Legal Affairs Department (Polhukam) DPP PKS, said.

"Departing from these concerns, PKS initiated a fiscal policy breakthrough to overcome the low purchasing power and reduce the burden of life difficulties that plagued the lower middle class. One of them is, PKS will fight for the exemption of income tax for workers up to 8 million per month if they win the 2019 general election ".

Quoted from tempo.co, the Prosperous Justice Party promised to fight for a tax exemption program for workers, employees, and employees who earn less than Rp. 8 million per month, if they later win the 2019 election, said a spokesman for the PKS election team (TPP), Handi Riza. This program is voiced by PKS because it is concerned about the decline in the purchasing power of the people, especially among the people who have middle to lower income in the last few years.

\section{d. Draft Law on the Protection of Ulama, Religious Leaders and Religious Symbols}

Quoted from pks.id Fighting for a Draft Law that has been eagerly awaited by Ulama, Religious Leaders, and all religious communities throughout the archipelago.

Protection is the partisanship of the State in protecting ulama, religious leaders, and religious symbols from all actions that threaten physical good, such as deterrence, dissolution, persecution, destruction, arson as well as non-physical such as intimidation, blasphemy, insults, harassment, etc., as well as all kinds of acts of criminalization of the law.

${ }^{34}$ Results of Interview with: Pipin Syofyan, Chair of the Political, Legal and Human Rights (Polhukam) Department of DPP PKS. On October 13, 2019, at the DPR / MPR RI Building, Fourth Floor, Senayan, South Jakarta.

${ }^{35}$ Results of Interview with: Pipin Syofyan, Chair of the Political, Legal and Human Rights (Polhukam) Department of DPP PKS. On October 13, 2019, at the DPR / MPR RI Building, Fourth Floor, Senayan, South Jakarta. 
Whereas what is meant by Ulama is Muslim leaders, who preach the teachings of the Islamic religion, which have Islamic scientific competence, have a noble character, and become role models of Muslims in studying the guidance of Islamic teachings. Ulama, in this case, also has other titles such as Habib, Kiyai, Ustadz, Teungku, Tuan Guru, Ajengan, and other titles that have the same meaning and position, While Religious Leaders are all religious leaders recognized in Indonesia other than Islam, such as Priests, Pastors, Priests, Monks, Pandita, and other names for the names of religious leaders in Indonesia.

The Symbols of Religions meant are all religious symbols that are respected by all official religions recognized by the Indonesian State, such as holy books, houses of worship, monotheism flags, images or images or writings that symbolize things that are sacred to all religions - recognized religion in Indonesia.

Quoted from the interview of researchers, Al Muzammil Yusuf ${ }^{36}$, Chairman of the Political Law and Human Rights (Polhukam) DPP PKS, said.

"The reason PKS is fighting for the bill on the protection of religious clerics and religious symbols is that ulemas and religious leaders are a great service in liberating the Indonesian people and participating in formulating the basic foundations of national and state life. Ulama and religious leaders have the right to be protected in their freedom to convey the teachings of their beliefs to the people. Religious scholars and leaders are the most vulnerable figures who are threatened both physically, non-physically, and criminalized by law enforcers due to the preaching they deliver. Symbols Religions are something that is respected and glorified in the teachings of each religion.

According to our research, from the field study and available data, we have concluded that the PKS campaign promise in the 2019 election is one of the attractions of the people choosing PKS in the 2019 election, although they do not yet know whether the promises can be fulfilled because PKS is the only opposition party. Current government. PKS claims that the campaign down the road using flashmob is quite effective in attracting the attention of the public.

\section{CONCLUSIONS}

The PKS communicative performance in the 2019 elections also played a role in encouraging party members' loyalty and solidity in carrying out activities and taking part in the party so far. Loyalty is demonstrated by obedience and obedience to party leaders' policies and decisions regarding an issue or party work. PKS in maintaining synergy with fellow cadres, fellow parties So that in maintaining good relations, the performance of the ritual, which is done by a daily briefing to monthly evaluations of the political elite in PKS to all levels related to plans for the future people.

36 Results of Interview with: Al Muzammil Yusuf, Head of Political, Legal and Human Rights (Polhukam) DPP PKS. On September 2, 2019, at the DPR / MPR RI Building, Fourth Floor, Senayan, South Jakarta. 
Secondly, the Performance of Desire, with the motto of serving the public, PKS Public Relations continues to express ideology, plans to the party's vision and mission to the people. Social Performance, PKS political public relations continues to maintain good relations with various parties not only with outsiders but fellow PKS cadres with weekly activities to strengthen cadres to holiday together. Political performance by collaborating with parties to give the impression of persuasion to the public about the positive reputation of the party. Enculturation performance, to empower its members, increase the ability to be more empowered.

Political public relations approach in the 2019 elections. PKS political public relations uses social media to the maximum to maintain the party's positive reputation. Fifth, PKS pays attention to international human rights, especially the conflicting Islamic State. This shows the concern of the party, especially for Muslims. PKS political public relations changes party slogans periodically to ward off issues that are felt under the times as an opposition PKS party shows concern and criticizes the government periodically. Create a community to consolidate cadres and also to seek people's attention.

\section{REFERENCES:}

Ardial. (2008). Komunikasi Politik. Medan: PT. Indeks.

Arifin, A. (2011). Komunikasi Politik. Yogyakarta: Graha Ilmu.

Farida I., \& Setiawan, R. (2018). Leadership In Cope With Prostitute In Social Department of Bandar Lampung. International Journal of Social Sciences And Development, Vol. 2 (1). 1-8. doi: 10.24967/saburaiijssd.v2i1.325

Heryanto, G.G, Komunikasi Politik Di Era Industry Citra, (Jakarta: PT. Laswell Visitama, 2010).

Heryanto, G. G. (2019). Literasi Politik Dinamika Konsolidasi Demokrasi Indonesia Pasca reformasi.Yogyakarta: Ircisod.

Jefkins, F. (2003). Public Relations, Edisi Kelima, Terjemahan Daniel Yadin. Jakarta: Erlangga.

Kerlinger. (2015). Metode Penelitian Komunikasi Prosedur, Tren, Dan Etika. Bandung: Simbiosa Rekatama Media.

Morissan. (2009). Teori Komunikasi Organisasi. Bogor: Ghalia Indonesia.

Mulyana, D. (2013). Komunikasi Politik Politik Komunikasi, Membadah Visi Dan Gaya Komunikasi Praktisi Politik. Bandung: PT. Remaja Rosdakarya.

Muqsith M.A., Muzykant V.L., Kuzmenkova K.E. (2019). Cyber protest: new media and the new social movement in Indonesia // RUDN Journal of Studies in Literature and Journalism. - 2019. - Vol. 24. - N. 4. - P. 765-775. DOI: 10.22363/2312-9220-2019-24-4-765-775 
Muqsith M.A. (2019). The Relationship of Political Socialization Messages Relations in Social Media Twitter with The Image of PKS. (Study: Political Socialization PKS Through @PKSejahtera Account). Jurnal Ilmu Komunikasi Ekspresi dan Persepsi. 2019. Vol 2 No. 1 P. 3-12. Doi: http://dx.doi.org/10.33822/jep.v2i1.972

Muqsith, M.A, \& Muzykant, V.L., (2019). Effect of Fake News for Democracy. Jurnal Cita Hukum, 7(3), 307-318. doi:https://doi.org/10.15408/jch.v7i3.12956

1Muqsith M.A., Muzykant V.L., (2019). How New Media Becomes a Platform for Public Participation. Средства массовой коммуникации в многополярном мире: проблемы и перспективы. Р. https://elibrary.ru/item.asp?id=42754557

Muqsith M.A., (2018). The Use of Hashtag in The Political Campaign. Средства массовой коммуникации в многополярном мире: проблемы и перспективы. P (352-354). https://elibrary.ru/item.asp?id=36910734

Nimmo. (2010). Komunikasi Politik: Khalayak dan Efek. Bandung: PT. Remaja Rosdakarya.

Nurul, H. (2006). Metodologi Penelitian Dakwah Dengan Pendekatan Kualitaif. Jakarta: UIN Jakarta Press.

Patton, D. B., \& Blaine, T. W. (2001). Public issues education: Exploring Extension's role", Journal of Extension, Vol. 39 (4).

Rittel, H. W. J., \& Webber, M. M. (1973). Dilemmas in a general theory of planning. Policy Sciences, 4. 155-169.

Setiawan, R. (2016). Peranan Etika Aparatur Sipil Negara Dalam Pelayanan Publik Pada Dinas Kependudukan Dan Catatan Sipil (Disdukcapil) Kota Bandar Lampung. Jurnal e-JKPP. Vol. 2 (2)

Setiawan, R. (2017). Partisipasi Publik Dalam Program Bantuan Listrik Pedesaan Masyarakat Kabupaten Mesuji. Jurnal e-JKPP. Vol. 3 (3)

Stephen, W. L., \& Karen, A. F. (2009). Teori Kounikasi (Theories Of Human Communication) Edisi 9. Jakarta Selatan: Salemba Humanika.

Witteman, H. (1988). Interpersonal problem solving: Problem conceptualization and communication use. Communication Monographs. Vol. 55 (4). 336-359. 